How to Cite

Setyaningrum, R., Zubaidah, T., \& Anhar, V. Y. (2018). Correlation between gender, age, education level, and working status with anti-tuberculosis drug uses (OATS) in patients with lung tb in Indonesia 2013. International Journal of Chemical \& Material Sciences, 1(1), 7-13. https://doi.org/10.31295/ijcms.v1n1.3

\title{
Correlation between Gender, Age, Education Level, and Working Status with Anti-Tuberculosis Drug Uses (OATS) in Patients with Lung TB in Indonesia 2013
}

\author{
Ratna Setyaningrum \\ Lambung Mangkurat University, Banjarmasin, Indonesia \\ Corresponding author email: ratnastyar@yahoo.com \\ Tien Zubaidah \\ Environmental Health Department, Health Politechnique, Health Ministry, Indonesia \\ Vina Yulia Anhar \\ Lambung Mangkurat University, Banjarmasin, Indonesia
}

\begin{abstract}
Lung TB is still being a public health problem in the world. Lung TB disease many attack age group productive. Most of who are from the group socio-economic and low levels of education that low. The low coverage recovery rates have had a negative impact on public health program achievement and success because it still gives an opportunity for transmitting Lung TB to other members of the family and community around it. To achieve recovery required order or loyalty treatment for every patient. Loyalty patients in medication dose without consultation OATS influenced by many factors. This research aims to analyze factors which affect the (OATS) Anti Tuberculosis uses in patients with Lung TB in Indonesia (The 33 provinces at the consecutive Indonesia Fundamental Health Research Survey in 2013). This research used a non-interference study with cross-sectional approach. A sample of research is household's members at the age of 15 consecutive that was diagnosed with Lung TB through inspection sputum and/or photo Lung by health workers through an interview. This research showed that most of pulmonary tuberculosis patients in the male gender (52.7\%), the range of the largest age group of 35-44 years $(21.3 \%)$, the highest educational level in the low educational level (73.9\%), work status many in the working group (60.1\%), and pulmonary tuberculosis patients more do not use OATS $60.4 \%$. Logistic regression analysis test result shows, there is a significant correlation between genders, age, levels of education with the use of OATS. No significant relationship between working status in patients with Lungs TB and the use of OATS (p-value=0.454). The characteristics patients with Lung TB (gender, age, levels of education) are the factors that influence significantly to this research and statistic, while status work is not significantly influenced in patients with Lung TB in Indonesia.
\end{abstract}

Keywords---age, gender, OATS use, working status, education level.

\section{Introduction}

Lung Tuberculosis (TB) is a chronic infectious disease and infectious diseases that closely linked to the state of the environment and on the community. Lung TB is infectious diseases caused by Mycobacterium tuberculosis. This disease is transmitted through the air that is zoster virus, sneezing, and coughing. Lung TB usually attacks the lungs but can also invade organs (Aditama, 2002). Lung TB is still being a public health problem in the world. Lung TB disease many attack age group productive. Most of who are from the group socio-economic and low levels of education that low (Aditama \& Tjandra, 1994). Lung TB Cancer is the cause of the death third biggest after 
cardiovascular disease and respiratory disease and is number one largest cause of death in the group infectious diseases (Crofton, 2002).

Lung TB disease that closely connected with the economy is weak and it is estimated 95 percent of the number of cases Lung TB happened in developing countries that are relatively poor (Health Department of RI, 2002). Lung TB is also a health problem in Indonesia. Expected every year there are 450,000 new cases Lung TBs, where about $1 / 3$ patients are in the Community Health Center, $1 / 3$ in hospital service, the clinic government and private sectors and $1 / 3$ found in unit health services that are not reached such as traditional treatment. Patients with Lung TB in most of Indonesian happened in the current age productive and socio-economic low (Health Department of RI, 2007). Establish experienced Lung TB in Indonesia has started since symposium was held in eradicating Lung TB Ciloto in 1969. But, until now the development in combating Lung TB has yet to show a pleasing result. Ha 1 this can be seen from the proportion deaths from Lung TB had been an increase from the year 1980, 1986, and 1992 in a row - at 8.4 percent, 8.6 percent, and 9.4 percent (Health Department of RI, 1996).

WHO data Global Report is available in Sub-Directorate of disease TB from the Directorate General of P2\&PL in 2010 said that the new cases TB in Indonesia in 2006 was 275 cases/100,000 people/year and in 2010 fell to 244 cases/100,000 people/year (Directorate General of P2\&PL, 2010). Data from Fundamental Health Research Survey in 2013 that prevalence Lung TBs are still in a position to do the same in 2007 and 2013 that is equal to 0.4 percent by Lung TB highest in West Java Province of 0.7 percent and the lowest in Bali Province, Lampung, and Riau of 0.1 percent (Health Department of South Kalimantan Province, 2013).

Disobedience patients in the treatment Lung TB make bacteria resistant to Lung TB in the body. Supervision during the process treatment that will take place cannot be accomplished by family and patients with itself. Sufferers feel treatment that lived did not give a significant impact on the effort cure rate Lung disease in relatively short time (Amiruddin, 2006). Community attitude that is thought that Lung TB is a cough feature that can be healed by itself by consuming cough medicine is sold freely also hampered relief and recovery Lung TB's. This situation is worrying, but Health Department has provided drug-free for patients with Lung TB treatment to the Community Health Center (Amiruddin, 2006). The low coverage recovery rates have had a negative impact on public health program achievement and success because it still gives an opportunity for transmitting Lung TB to other members of the family and community around it. In addition, make it possible for him there were resistance germs TB Lung to Drug Anti Tuberculosis (OATS), adding to disseminate Lung TB, increasing pain and deaths from Lung TB (Amiruddin, 2006).

To achieve recovery required order or loyalty treatment for every patient. OATS blend short-term and Supervisors Swallowed Drugs (PMO) is a strategy to ensure recovery patients. Even though this guide a drug used both but when patients are not treated in an orderly manner and generally treatment results will be disappointing (Director General of P2M \& PLP, 1997). Loyalty patients in medication dose without consultation OATS influenced by many factors.

\section{Purpose}

This research aims to know the relation of gender, age, levels of education with the OATS use in patients with Lung TB in Indonesia's relevant centers material inputs and evaluation in determining and determine the direction in the prevention efforts health policy and a decline in the lung disease TB Indonesia (The 33 provinces at the consecutive Indonesia Fundamental Health Research Survey in 2013).

\section{Research Method}

This research was a study non-interference with the design or cut bars (cross-sectional). This research will be done in 33 (thirty-three) provinces in Indonesia (Figure. 1). Time or planned for the month of October-December 2014. The population in this research is the household members in 33 provinces at the age of 15 consecutive Fundamental Health Research Survey in 2013. Sample households research is at the age of 15 consecutive that was diagnosed with Lung TB through inspection sputum and/or photo Lung by health workers through an interview. 


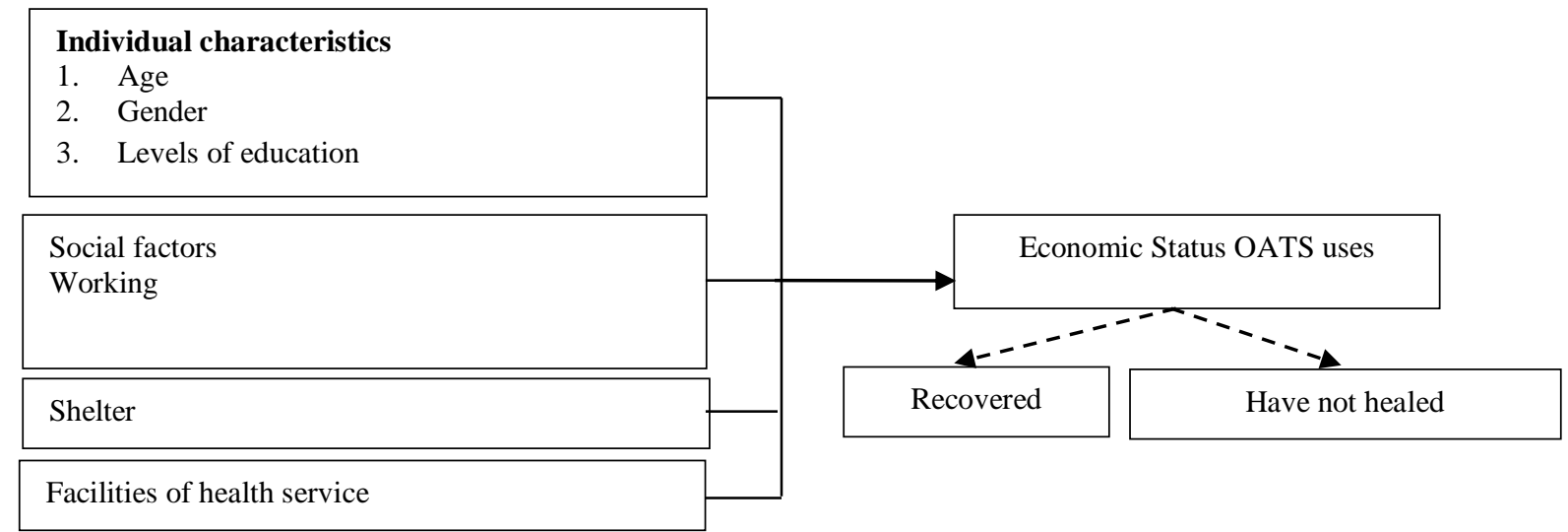

Figure.1 Conceptual Framework of Research

An instrument that used in this research is secondary data survey results in Basic Health (Fundamental Health Research Survey) in 2013. Researchers were using a questionnaire structured that was questionnaires for the household and questionnaires to individuals who are chosen. All of the data is being processed and analyzed by SPSS program. Analysis of univariate used to see frequency distribution and average test, analysis of bivariate used to assess relations between the independent and dependent and analysis of multivariate done trial regression logistics to know the relation of gender, age, levels of education with the OATS use.

\section{Results and Analysis}

Total Number of respondents in this analysis was 722,329 people. From that number respondent who are diagnosed Lung TB by health workers for the rest of his life as many as 14,098 people $(1.95 \%)$.

1) Individual Characteristics (Gender, Age, and Levels of Education)

Table 1

Frequency distribution of respondents' gender

\begin{tabular}{llll}
\hline No & Gender & Frequency & The percentage (\%) \\
\hline 1 & Men & 7431 & 52.7 \\
2 & Women & 6667 & 47.3 \\
& Total & 14098 & 100 \\
\hline
\end{tabular}

Table 2

Frequency distribution of respondents' age

\begin{tabular}{llll}
\hline No. & Age (in) & Frequency & The percentage $(\%)$ \\
\hline 1 & $15-24$ & 2206 & 15.6 \\
2 & $25-34$ & 2444 & 17.3 \\
3 & $35-44$ & 3008 & 21.3 \\
4 & $45-54$ & 2777 & 19.7 \\
5 & $55-64$ & 2124 & 15.1 \\
6 & $65-74$ & 1121 & 8.0 \\
7 & $\geq 75$ & 418 & 3.0 \\
Total & & 14098 & 100 \\
\hline
\end{tabular}


Table 3

Frequency distribution of respondents' levels of education

\begin{tabular}{llll}
\hline No. & Levels of Education & Frequency & The percentage $(\%)$ \\
\hline 1 & Low & 10423 & 73.9 \\
2 & High & 3675 & 26.1 \\
Total & & 14098 & 100 \\
\hline
\end{tabular}

The table 1,2, and 3 are showing a distribution of gender, age and levels of education patients with Lung TB in Indonesia in 2013.

Based on table 1 it is known that genders who are suffering from Lung TB based on data Fundamental Health Research Survey 2013 more men than women of 52.7 percent. Based on the table 2 that was known that age range votes that suffer from Lung TB range are age 35-44 years of 21.3 percent. Based on table 3 that a patient with Lung TBs was known has low levels of education more than higher education that is equal to 73.9 percent.

2) Social-Economic Factor (Status In Cooperation)

Table 4

Frequency distribution of respondents' work status

\begin{tabular}{llll}
\hline No. & Work status & Frequency & The percentage $(\%)$ \\
\hline 1 & Do not work & As many as 5625 ITEMS & 39.9 \\
2 & Work & 8473 & 60.1 \\
Total & & 14098 & 100 \\
\hline
\end{tabular}

Table 4 is showing a distribution work status Lung TB sufferers in Indonesia in 2013. Based on table 4 it is known that patients with Lung TB more in the current work from that do not work that is equal to 60.1 percent.

3) Relations between Genders, Age, Levels of Education, Status in Cooperation with OATS Use

Table 5

Test result of regression variables to logistics that are examined

\begin{tabular}{llll}
\hline No. & Variable & $P$ & OR \\
\hline 1 & Gender & .000 & 1,368 \\
2 & Age & .000 & .821 \\
3 & Levels of Education & .000 & 1,182 \\
4 & Work status & .454 & 1,030 \\
\hline
\end{tabular}

The result of the analysis on table 5, shows that there is a significant relationship between genders, age, levels of education with OATS use. The variable jobs patients status with Lung TBs do not affect significantly OATS (pvalue $=0.454)$.

Table 6

Test result regression variables logistics to which have an effect on OATS use

\begin{tabular}{llll}
\hline No. & Variable & $P$ & OR \\
\hline 1 & Gender & .000 & 1,354 \\
2 & Age & .000 & .822 \\
3 & Levels of Education & .000 & 1,185 \\
Constant & .000 & 1,430 \\
\hline
\end{tabular}

The result of the analysis on table 6 , shows that there is a significant relationship between genders, age, levels of education with OATS use (p-value=0.000). 
Gender

Gender is closely related to the occurrence of Lung TB's. According to Ismen (2000) in Chandra Wibowo et al., (2004) or in the developed countries must be obtained a man's risk of contracting the contact more than in women.

Based on Fundamental Health Research Survey data in 2013, many Indonesian attacks by Lung TB in the male as much as $52.7 \%$. Multiple regression logistic analysis result shows that gender significantly exceeds OATS in patients with Lung TB $(\mathrm{p}=0.000)$. The odds ratio of 1.354 showed that patients who are men with Lung TB's 1.354 times to OATS use that patient who was women with Lung TB's. A number of reasons why women are not diagnosed properly or did not receive adequate treatment (Aditama, 2002):

a) There is no time because his workloads to take care their family

b) The cost and transportation problems

c) The need for a friend who is a man who accompanied to go to health facilities

d) Stigma or disability, because some tuberculosis can cause infertility

e) Levels of education who is relatively low, so lack of information about symptoms and treatment for tuberculosis

f) Factors socio-cultural document that had blocked women to contact with health officials men.

Age

Age is the variable that is always observed in the investigation. In general, very young age and old age more vulnerable or less immune to certain diseases as the group has a less body resistant (Notoatmodjo, 2003). In Genesis of Lung TB, until the puberty age between male and female did not show the difference genesis Lung TB's. But after passing through puberty age to adults there are differences mixed in various countries.

Lung TB in Indonesia many attacks on productive ages (35-44 years) as much as 21.3 percent. This is because at the age productive people tend to have a high mobility so that it is possible for TB germs to have been exposed to more than (Zuliana, 2009). Multiple regression analysis results logistics in that age significantly influenced by OATS use in patients with Lung TB ( $\mathrm{p}=0.000$ ). If we see from the odd ratio, it showed that the use OATS in patients with Lung TB's with young age 0.822 times to OATS use compared to using OATS in patients with Lung TB old age.

Age is one of the characteristics of the great page. Age has a relationship with a high-risk exposure, the amount, and nature of resistance. Different experiences to the problem health/disease and decision making are influenced by individual age. According to Bart (1994) said that the age-old/go tend to follow advice doctors, which have a sense of responsibility, which, however, more carefully, which has high moral standards and more kindness from at a young age (Bart, 1994).

\section{Levels of Education}

Levels of education patients with Lung TB most categories in low of 73.9 percent. Multiple regression analysis result logistics in that age variables affect the OATS use in patients with Lung TB ( $\mathrm{p}=0.000)$. Based on the odds ratio, showed that the OATS use in patients with Lung TB with low levels of education 1.185 times to OATS use compared to using OATS in patients with Lung TBs with higher education.

More than levels of education are not always accompanied by the better compliance level drink the medicine. This was not forever patients with low education level knowledge about Lung TB low and not all that educated than have the knowledge that was about Lung TB's. Thus, the police officials need to always provide information on how to take medicine and for how long treatment that should be followed by patients, each delivered drugs to patients (Wuryanto, 2008). In addition, compliance has influenced by information received factors of respondents. This time there has been an advertisement that provides information about the importance treatment for tuberculosis free on the television, radio, and leaflets in the Community Health Center and banners. Thus electronic and media print has provided much information to respondents.

\section{Working Status}

Jobs patients' status with Lung TB in most categories works of 60.1 percent. Multiple regression logistic analysis result shown that status variable work is not significantly exceeding OATS in patients with TB Lung $(\mathrm{p}=0.454)$. This was in line with the result or Zuliana (2009) stated that compliance level of Lung TB treatment respondents who work and do not work is almost the same. Respondents, the majority of which are in the productive age fear of losing the productivity (Bart, 1994). 


\section{Conclusion}

Based on the results of research can be concluded that the characteristics patients with Lung TB (gender, age, levels of education) are the factors that influence significantly to this research and statistic, while status work is not significantly influenced in patients with Lung TB in Indonesia. Recommendation for successful treatment Lung TB is closely connected with the adequacy OATS use. OATS use closely connected with loyalty patients with TB in treating this disease even to the stage healing. The loyalty of patients with TB healing process toward is a problem that must be dealt with an integrated from various parties. The first is patients with TB itself and the second is the

family patients who continued to carry out a clampdown mainly on the adequacy OATS use in patients with Lung TB's. A level of education is not always associated with the level of knowledge and level of compliance OATS use. Thus the information and the role and PMO were needed.

\section{Acknowledgments}

The authors are grateful to Board of Health Research and Development, Indonesian Health Ministry for their support to collecting data and funding by Basic Health Survey and its report. 


\section{References}

Aditama, T. Y. (1994). Tuberkulosis Paru. Masalah dan Penanggulangannya.

Aditama, T. Y. (2002). Manajemen administrasi rumah sakit. Penerbit Universitas Indonesia.

Billaiya, R., Malaiya, S., \& Parihar, K. S. (2017). Impact of Socio Economic Trends on Students in Quality Education System. International Journal of Social Sciences and Humanities (IJSSH), 1(1), 16-20.

Firdaus, K. M. A. Z., \& Widodo, A. (2012). Pengaruh peranan pengawas menelan obat (pmo) Terhadap keberhasilan pengobatan Tb paru di wilayah kerja puskesmas Baki Sukoharjo (Doctoral dissertation, Universitas Muhammadiyah Surakarta).

Fleischmann, R. D., Alland, D., Eisen, J. A., Carpenter, L., White, O., Peterson, J., ... \& Hickey, E. (2002). Wholegenome comparison of Mycobacterium tuberculosis clinical and laboratory strains. Journal of bacteriology, 184(19), 5479-5490.

Health Department of Republic Indonesia (RI). (1996). Guidelines Tuberculosis and Managements. Jakarta.

Health Department of Republic Indonesia (RI). (2002). Guidelines National Combating Tuberculosis. Jakarta.

Health Department of Republic Indonesia (RI). (2007). Guidelines Tuberculosis and. Updates. 2nd Edition. Jakarta.

Health Department of South Kalimantan Province. (2013). Executive Summary. Banjarmasin.

Lestari, T., Probandari, A., Hurtig, A. K., \& Utarini, A. (2011). High caseload of childhood tuberculosis in hospitals on Java Island, Indonesia: a cross sectional study. BMC Public Health, 11(1), 784.

Malaiya, S., Shrivastava, A., Prasad, G., \& Jain, P. (2017). Impact of Medical Education Trend in Community Development. International Journal of Health Sciences (IJHS), 1(1), 23-27.

Notoatmodjo, S. (2003). Pendidikan dan perilaku kesehatan.

Pinquart, M., \& Sörensen, S. (2003). Differences between caregivers and noncaregivers in psychological health and physical health: a meta-analysis. Psychology and aging, 18(2), 250.

Santha, T., Garg, R., Frieden, T., Chandrasekaran, V., Subramani, R., Gopi, P., ... \& Narayanan, P. (2002). Risk factors associated with default, failure and death among tuberculosis patients treated in a DOTS programme in Tiruvallur District, South India, 2000. The International Journal of Tuberculosis and Lung Disease, 6(9), 780788.

Wirawan, I. G. B. (2018). Surya Namaskara Benefits for Physical Health. International Journal of Social Sciences and Humanities (IJSSH), 2(1), 43-55.

Wuryanto, M. A. (2008). Tingkat Kepatuhan Penderita Malaria Vivax Dalam Minum Obat Serta Faktor Yang Mempengaruhinya Studi Pada Penderita Malaria Vivax Di Kabupaten Banjarnegara Tahun 2005. Jurnal Promosi Kesehatan Indonesia, 3(1), 24-30.

Zuliana, I. (2009). Pengaruh Karakteristik Individu, Faktor Pelayanan Kesehatan Dan Faktor Peran Pengawas Menelan Obat Terhadap Tingkat Kepatuhan Penderita Tb Paru Dalam Pengobatan Di Puskesmas Pekan Labuhan Kota Medan Tahun 2009. 